\title{
Architects and construction of religious buildings in Bessarabia (second half of the XIX century - 1917)
}

https://doi.org/10.52603/arta.2021.30-1.04

\author{
Rezumat \\ Arhitecți și construcția edificiilor de cult în Basarabia \\ (a doua jumătate a secolului al XIX-lea - 1917)
}

Arhitectura religioasă din Basarabia, începând cu secolul al XIX-lea până în 1917, constituie obiectul unor cercetări speciale, deoarece mulți arhitecți, care au activat la acea vreme au proiectat clădirile mănăstirilor, bisericilor ortodoxe, bisericilor catolice, bisericilor luterane, capelelor, caselor pentru oficierea cultelor și sinagogilor. În această perioadă s-au remarcat mai mulți arhitecți, precum Luka Zaușkevici, Alexandru Bernardazzi, Leopold Scheidewandt, Karl Gasquet, Gheorghe Cupcea, Mihail Seroținski, VladimirȚiganco, Lavrenti Lozinski ș.a. Moștenirea lor în arta bisericească se caracterizează prin diversitate și necesită o cercetare aprofundată. Pe de o parte, studiul prezintă pagini necunoscute legate de istoria arhitecturii și practicii arhitecturale creative din Basarabia în perioada enunțată. Pe de altă parte, materialele de arhivă ce țin de subiectul în discuție, descoperite recent, vor putea completa lista de autori ai mai multor edificii de cult din Basarabia.

Articolul conține atât materiale publicate, cât și documente de arhivă, înclusiv câteva proiecte de clădiri religioase construite în Basarabia. Datorită acestora descoperim noi fațete ale talentelor arhitecților, care prezintă interes atât pentru istoria arhitecturii, cât și pentru conservarea bogatului patrimoniu cultural al Republicii Moldova.

Cuvinte cheie: arhitecți basarabeni, biserici, clădiri religioase, design, școală parohială, construcție.

\section{Summary \\ Architects and construction of religious buildings in Bessarabia \\ (Second half of the XIX century - 1917)}

Religious architecture in Bessarabia from the beginning of the XIX century to 1917 is the subject of special research, since many architects, who worked during this period designed the buildings of monasteries, Orthodox, Catholic and Lutheran churches, chapels, houses of worship and synagogues. The creativity of such architects as Luka Zaushkevich, Alexander Bernardazzi, Leopold Scheidewandt, Karl Gasquet, George Cupcea, Mikhail Serotsinsky, Vladimir Tiganco, Lavrentii Lozinsky and others was especially vivid. Their heritage in church art is very diverse and worthy of careful study. On the one hand, the study opens new unknown pages related to the history of architecture and the creative practice in Bessarabia during the specified period. On the other hand, the newly discovered archival materials on this topic will be allow to reveal and supplement the authorship of many religious buildings in Bessarabia.

The article examines both published materials and archival documents, some designs of religious buildings built in Bessarabia, due to which new facets of the talents of architects become more obvious and are of interest both for the history of architecture and, in general, for the preservation of the rich cultural heritage of the Republic of Moldova.

Key words: Bessarabian architects, religious buildings, churches, design, parish school, construction.

From the XIX century until 1917, religious architecture in Bessarabia is the subject of special research, because many architects, who worked during this period, designed the buildings of Orthodox, Catholic and Lutheran churches, monasteries, chapels, houses of worship and synagogues.
Their heritage in ecclesiastical art is very diverse and worthy of careful study. On the one hand, the research opens new unknown pages related to architectural creative practice in Bessarabia during the specified period. On the other hand, the newly discovered archival materials on this topic will al- 


\section{Arta antică, medievală și modernă}

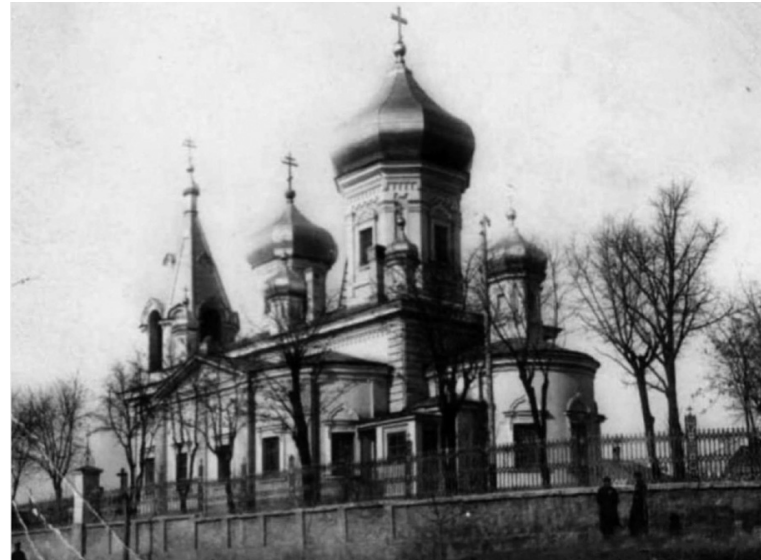

Fig. 1. St. Great Martyr Tyrone church in Chisinau. Architect L. Zaushkevich.

low identifying the authorship of many religious buildings of Bessarabian architects.

To begin with, let us turn to the work of the architect Luka Karpovich Zaushkevich, who was the author of the famous Triumphal arch on the Cathedral square of Chisinau [1]. According to his service record, drawn up in 1844 [4, p. 64 inv. 67], L. Zaushkevich descended from the family of a priest. Even before graduating from the Kiev Theological seminary, having passed exams related to civil architecture, according to the order of the Bessarabian civil governor on June 10, 1832 he was appointed as staff assistant of the Bessarabian regional architect [5, p. 24-24 inv.]. In 1836, architect L. Zaushkevich prepared a drawing for the construction of chandeliers and iron choirs in the Chisinau Cathedral church [3, p. 36-50]. The Summer Church of the Ascension of the Lord of the Hirjauca Monastery was erected in 1836 by architect Zaushkevich [1, p. 154]. In 1838, under his leadership, the Chisinau Nativity of the Mother of God Church, which suffered after the earthquake that occurred on January 11 of that year, was repaired. On May 12, 1839 L. Zaushkevich was transferred from the position of assistant to the regional architect to the vacancy of the Chisinau city architect and served for 24 years [1]. In the same year, the architect drew up a plan and the estimates for the construction of the fence of the Church of St. Michael in the city of Cahul, which was built by architect Boffo [6, p. 9].

In St. Petersburg, the Russian State Historical Archive keeps the documents with the report of the Bessarabian Regional Construction and Road Commission on the erection of a church in

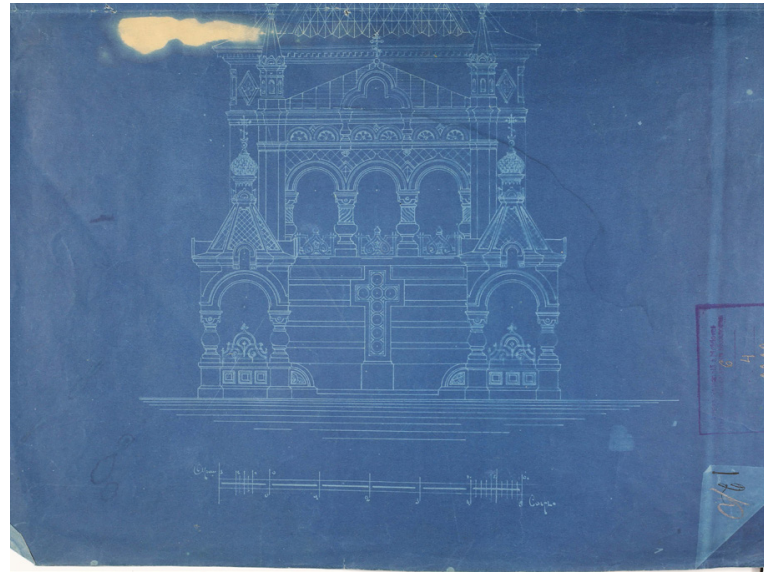

Fig. 2. The church chapel of the women's gymnasium in Chisinau (a part of the project). Architect A. Bernardazzi (NARM).

the name of St. Great Martyr Tyrone in Chisinau, dated from June, 6 to September 7, 1855. On June 23, 1855 the Bessarabian Regional Construction and Road Commission sent a report with a project submitted for approval and a plan of the area for the construction of a church in the name of the Great Martyr Tyrone according to the order of a merchant of the second guild Anastasii Ciuflea in Chisinau. The Construction and Road Commission recognized this project as satisfactory in terms of architecture and the correspondence to the drawings of architect Ton, which were taken into the leadership of the construction of churches. On July 16, the same year A. Ciuflea sent a petition with a request to approve the project for erection in Chisinau at his own expenses. "To accomplish this godly deed, my declining years require an early start of the construction of the temple," wrote merchant Ciuflea [1, p. 158-159]. The project was sent for consideration to the Department of Projects and Estimates, where it was concluded that it was necessary to "redo it both for the sake of the facade and for greater stability, without leaving the size of the local authorities"[1, p. 159]. On August 30, 1855 the Bessarabian Regional Construction and Road Commission presented the final project for the construction of a church in the name of the great martyr Theodor Tyron in Chisinau, and for greater plausibility, the facade was redone in the main directorate of communications and public buildings while maintaining the dimensions [1, p. 159] (Fig. 1).

This year marks the 190th anniversary since the birth of the remarkable architect from Switzerland, the Italian by origin, Alexander Iosi- 
fovich Bernardazzi, who created many various historical buildings in Ukraine, Bessarabia and Poland. Truly, the new architectural period in Bessarabia begins with his name [2, p. 38]. In the archival documents according to the report of the Bessarabian Construction and Road Commission of May 26, 1856 [7, p.14], "unfulfilled by the former city architect Luca Karpovich Zaushkevich... were transferred for the execution to architectural assistant Bernardazzi, who is in charge of correcting the position of the city Architect" [26, p. 226]. As for the religious buildings, according to the architectural magazine "Zodchii" (Architect), in Bessarabia he built: the school of the Lutheran parish, the church in the village Ustia, the church of women's gymnasium; the Catholic chapel in Tighina (Bender) $[19$, p. 91].

Until recently, there was extremely limited information about the stone church, which once existed in the village of Ustia. On February 2, 1859 by the decree of the Chisinau Spiritual Consistory, the building was abolished due to dilapidation. In 1860 , in the village of Ustia, which was one of the estates belonging to the Jerusalem monastery, the construction of a new stone church began, designed by architect A. Bernardazzi and approved by the Bessarabian Construction and Road Commission on May 30, 1860. At that time he was still a fairly young specialist, but already holding a responsible post of Chisinau city architect. He also carried out technical supervision, checking the quality of the work performed at each stage of construction: "on the $21^{\text {st }}$ of August, 1860, I witnessed the work on the construction of a church in the village, the estuary by the master Droplev and found that the work was being done correctly, and it was possible to start the arrangement of vaults and arches", architect Bernardazzi informed about this building [30]. The construction of the church building lasted less than 2 years and was fully completed by the fall of 1861, as evidenced by the following document: "The certificate of September 1861 on the 11th day is issued to the contractor Feodosii Droplev that after the construction of the church in the village of Ustia on the Dniester, his work finally was finished and the church was completed at once".., architect A. Bernardazzi wrote in the documents [30]. "In the village of Ustia, a new, stone, iron-covered church was built in 1861, with domes and a bell tower, of magnificent architecture, with a new iconostasis and clerical utensils; a good stone fence was erected around the church and only 12,500 rubles were spent in silver [30]. "The church in the village of Ustia was consecrated in the name of St. George the Victorious on April 23, 1862. In the post-war period, the building of the church was in poor condition for a long time and was subsequently pulled down [30]. It is also interesting that the building does not exist today, but it is listed in the current "List of Monuments of the Republic of Moldova, protected by the State" as "architectural monument of national importance" [24, p. 17].

In 1893, according to Bernardazzi's project, the Greek Church of St. Panteleimon was erected in Chisinau, which is still located here, at the corner of Vlaicu Pircalab and the 31st of August, 1989 streets. The metal fence with an openwork pattern and Orthodox crosses successfully emphasizes the Byzantine style of this church. "The corner solutions of the main facade with the entrance, as well as the layout of the volumes of the parts of the building are impressive." [21, p. 45] During the erection of the Greek Church in Chisinau (18891890), A. I. Bernardazzi used "a system of four intersecting arches instead of pylons, in which a domed drum takes up its position. This design is very convenient in church architecture, as it allows the worshiper to see the altar from any place. The iconostasis was very interesting from an artistic point of view and it is built in the Byzantine style" [21, p. 44]. The architect used natural shell rock, which was the main building material. "The alternation of limestone-shell rock in light and grayish tones, as well as the combination of red and yellow bricks looked artistically expressive" [21, p. 44].

According to the project of A. I. Bernardazzi, the church chapel of the women's gymnasium was built in Chisinau in 1895, whose building continues to adorn the city today. "There are the onionshaped domes, crowning facades, turrets, color combination with decorative wrought-iron lattices and all these emphasize the monumental character of the building" [21, p. 44]. "Two entrances from the side of the main facade are arranged with protruding openly visible ceremonial vestibules in the form of terraces with an interesting colonnade made of limestone-shell rock" [21, p. 44]. It's important that the project of the Home church at Chisinau women's gymnasium of 1895 has been preserved in the National Archive of Moldova [8] (Fig. 2).

Located in the center of the city of Ungheni, the temple in the name of the Blessed Grand 


\section{Arta antică, medievală si modernă}

Duke Alexander Nevsky was built according to the project of A. I. Bernardazzi to commemorate the victories of Russian weapons in the fight against the Turkish yoke and the liberation of the Moldovan lands. Bernardazzi created the project, after which the church was built in 1903-1905. It's interesting that a plan of the cathedral is a circle.

Leopold Ivanovich Scheidewandt was a civil engineer of the Bessarabian Chamber of State Property [28, p. 133]. According to the Decision of the Department of the Ministry of Internal Affairs of Bessarabia of December 3, 1878, Scheidewandt "graduated from the course of science at the Engineering-Topographic Department of the Forestry and Land Survey Institute with the title of engineer trainee... was appointed to the position of Chisinau city architect" [9]. Scheidewandt "was also engaged in detailed photographing of state villages on the plan" [9]. From his certificate of service, it is known that he conscientiously fulfilled his duties from 1852 to 1869 , when Scheidewandt built many new churches in Akkerman as well as Bendery counties. He built a new bell tower in the village Petropavlovca of Akkerman district and remade church buildings in the villages Carahasani, Copceac, Pavlovka and others of Akkerman district. All the aforementioned religious buildings were made firmly and correctly by Scheidewandt. In 1895 Leopold Scheidewandt drew up a project for the addition of a cast-iron staircase in the women's section of the main synagogue in Chisinau [10, p. 14] (Fig. 3).

According to the archival documents in 1863 1864 the architect Grigorii Stepanovich Lozinsky conducted the technical supervision of the construction of a new stone Archangel-Mikhail

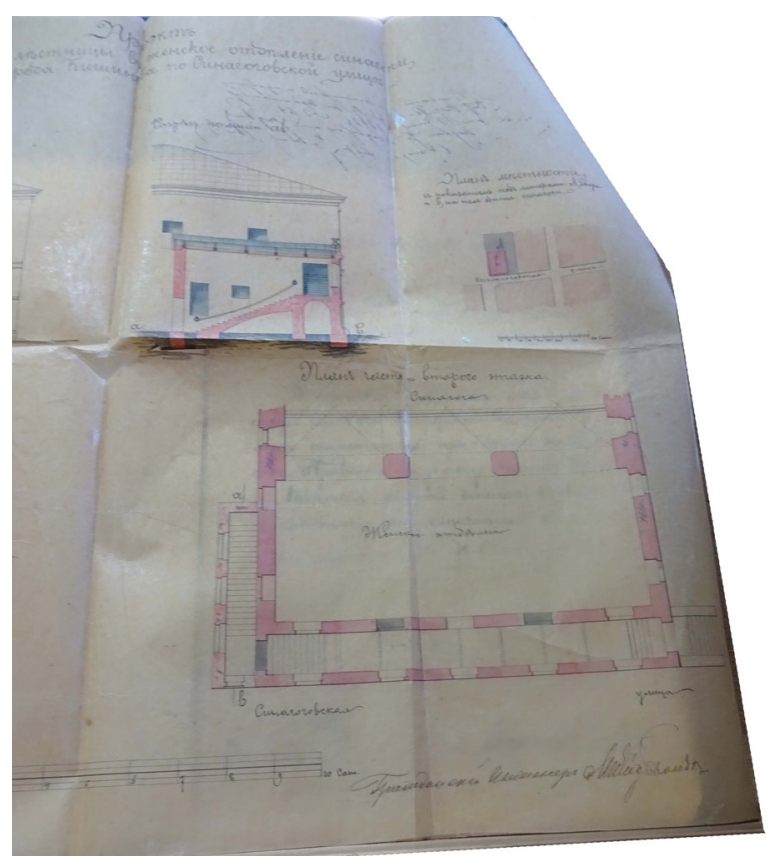

Fig. 3. The cast-iron staircase in the women's section of main synagogue in Chisinau (a part of the project) Architect L. Scheidewandt (NARM).

church in the village Durlesti of Chisinau district. The Russian State Historical Archive (RGIA) of St. Petersburg keeps archival documents referring to the drawing up of project for the construction of a stone church in the name of the Holy Trinity in Chisinau in 1865 [17] (Fig. 4). The project for the construction of this church in the Muncesti sector, Malina mare region of Chisinau, namely: all frontal and lateral facades and sections were considered on April 14, 1864. The general meeting of the Bessarabian Construction and Road Commission decided that "both in particular and in general, it's quite satisfactory and its purpose

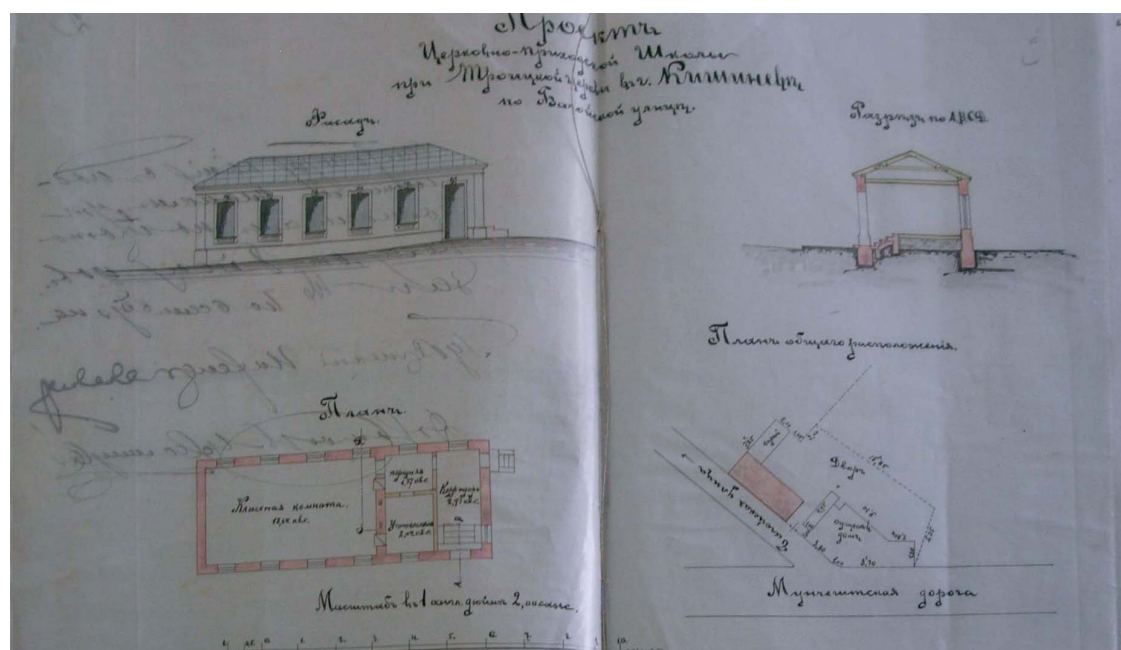

Fig. 4. The project of a parish school at the Trinity Church in Chisinau (NARM). 


\section{Arta antică, medievală si modernă}

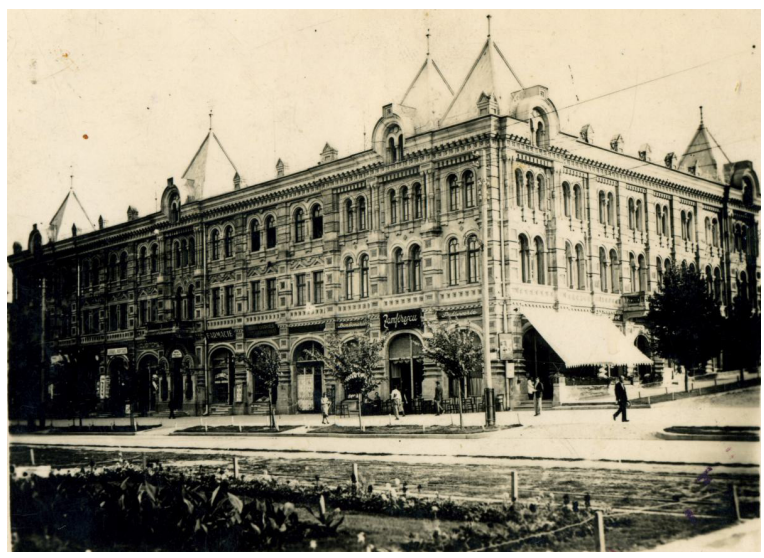

Fig. 5. Chisinau diocesan house. Architect G. Cupcea.

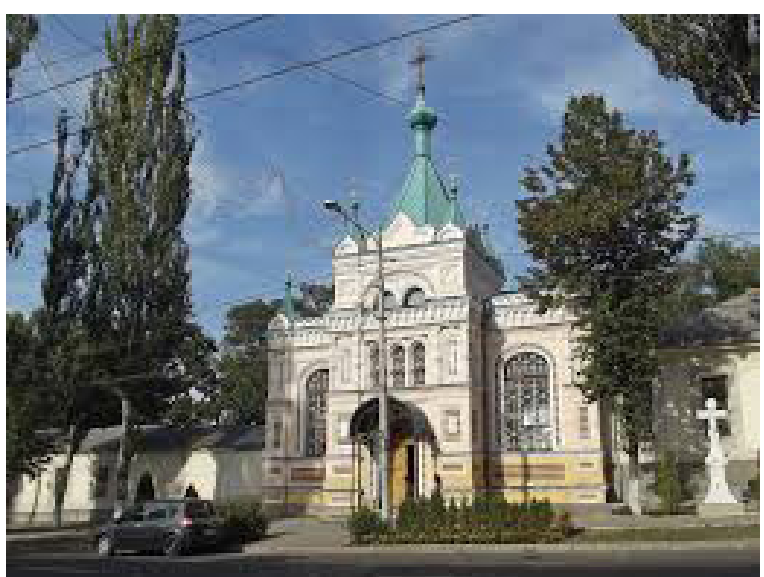

Fig. 6. St. Nicholas church, built at the Chisinau. Architect V. Tiganco.

was appropriate" $[17$, p. 8]. The plan of the outskirts of Chisinau, whose compiler was Lavrentii Klementyevich Lozinsky, indicated the place where it was supposed to build a church in the name of the Holy Trinity. [17, p. 9]. On May 20, 1865 the project was approved in Tsarskoe Selo [17, p. 10-12], and on June 6, 1906 the Construction Department of the Bessarabian Provincial Government approved the project for the erection of a parish school at the Trinity Church, and this decision was sent to the Chisinau Diocesan school Council [11, p. 3].

The RGIA keeps archival documents on the construction of new buildings for the Chisinau Theological Seminary in 1898 [18]. In January 1898, the Economic Department under the Holy Synod appealed to the Holy Governing Synod about the need to build new buildings for the Chisinau Seminary and demolish the most dilapidated ones. The Chief Prosecutor of the Synod has seconded the former architect of the Economic De- partment under the Synod Vasilii Mikhailovich Elkashev, who appealed to Chisinau with the goal to inspect the existing buildings and give appropriate instructions regarding the drafting of the buildings necessary for the seminary, as well as to find out which of the old seminary buildings were subjects to demolition and what designation could be given to the buildings being preserved [18, p. 1-1 inv.]. The Synod of January 28, March 171898 was allowed to carry out work on the construction of new buildings and alteration of existing ones.

Architect George Vasilievich Cupcea [27] designed religious buildings. According to archival documents, he worked as architect in the Construction Department of the Bessarabian Provincial Government. In the period from 1906 to 1916 , G. Cupcea served as diocesan architect and designed numerous objects of the Bessarabian Church. On March 13, 1918 he was appointed as assistant manager of the Technical and Construction Department of the Ministry of Internal Affairs of Bessarabia. Among his many projects, the construction of the Diocesan House was one of the most significant, which played an important role in the history of the Orthodox Church of Bessarabia in the first half of the XX century. The Chisinau diocesan house (not preserved) was built according to the project of architect George Cupcea in a relatively short period of time, starting with the laying of the foundation on August 26, 1910 and the consecration of the building on December 18, 1911. Initially, the main goal was set to build a structure for the enlightenment of the Orthodox population, as well as the placement in it of all the spiritual institutions of the Chisinau diocese. It is known that this house was also called "Seraphim's" in the honor of the Bishop of Chisinau His Grace Seraphim Chichagov, considering him an architect, for his worthy contribution to the construction of this educational diocesan center of Bessarabia. The majestic threestoryed building, built in the Russian-Byzantine style was located in the center of Chisinau, not far from the Metropolitanate on the side of Bishop's Square facing the street Alexandrovskaya (today this is Stefan cel Mare Boulevard) (Fig. 5). It housed various diocesan institutions: the library of the Christian brotherhood, the candle management, a museum, a church history archaeological society etc. The main hall of the Orthodox folk audience occupied two floors. The entire third floor was given over to the boarding school for 


\section{Arta antică, medievală și modernă}

psalmists with the placement there of classes, roo$\mathrm{ms}$ for living. As for other architectural projects, George Cupcea drew up a project for a church in the village Shagani of Izmail district in 1903. In 1910 he prepared the estimates for the repair of the Annunciation Church in Chisinau. In 1912 he made the estimates for the renovation of Buiucani St. Archangel Michael Church. He was the author of the project of the Diocesan candle factory, whose building did not survive either. According to statistics, this architect "built and rebuilt 280 churches, 40 schools, 20 parish schools and other buildings in Bessarabia" [23, p. 217].

Karl Osipovich Gasquet was the son of the famous architect Joseph Gasquet, born in Chisinau in 1838. After graduating from the Petersburg Civil Engineering Institute of Civil engineering department, he continued to work in Chisinau. In 1892 Karl Gasquet made the estimates and developed a project for the addition of a bell tower and a vestibule in the village Sireti of Chisinau district [23, p. 212-213]. In 1901 he took part in the construction of a church at the Second male gymnasium in Chisinau together with the architect Mikhail Serotsinsky [12; 13, p. 27].

After graduating from the Riga Polytechnic Institute, architect Vladimir Nikolaevich Tiganco returned to Chisinau and worked as an architect at the Chisinau Insurance Society [23, p. 212-213]. Vladimir Nikolaevich is the author of the project of St. Nicholas church, built at the Chisinau Zemskii Hospital in 1901 (Fig. 6). Today this church is located at the Stefan cel Mare Boulevard, 90.

Luka Nazarievich Semkov-Savoisky was a hereditary nobleman, state councilor and architect [23, p, 220]. In 1878, being assigned to service in Bessarabia, he worked as an engineer in the Construction Department of the Bessarabian Provincial Board. In 1879, he designed the stone bell tower of the Novonyametsky monastery.

Architect Mikhail Stepanovich Serotsinsky having received education at the St. Petersburg Civil Engineering School was appointed in 1873 to the post of the Bessarabian Diocesan architect, which he held until 1905 [23, p. 220]. More than 300 churches were built in Bessarabia with his participation. In $1878 \mathrm{M}$. Serotsinsky took part in the reconstruction of the Chuflinskaya or Theodor-Tyron church. In 1880, the building of the Theological School was erected (now the Academy of Theology is at the corner of Kogalniceanu and Banulescu-Bodoni streets) and the Sretensky

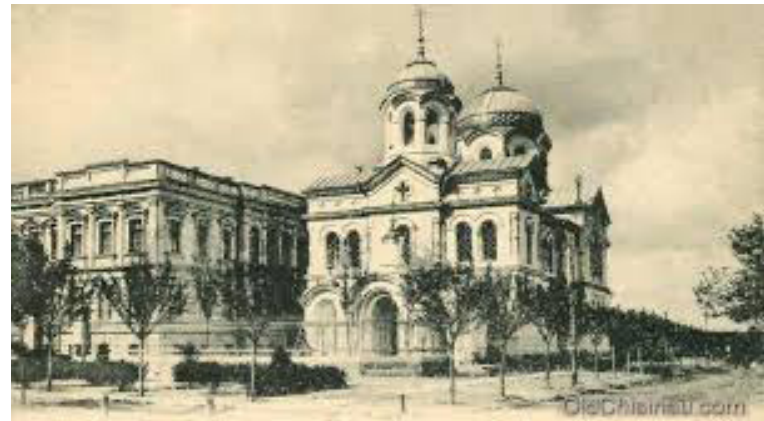

Fig. 7. St. Constantine and Helena church in Chisinau. Architect M. Serotsinsky.

Church at the Theological School in Chisinau. In 1899, he supervised the construction of the Church of All Mourners in joy of Alexander Nevsky brotherhood. Some time after the construction of the building of the Second men's gymnasium in 1895 , the question arose about the construction of a church at this institution. In 1899 the collegiate councilor Konstantin Aleksandrovich Namestnik donated a large sum of money for the erection of the church on the condition that it will be given the name of Saint Constantine and Helena. The construction began in 1900 and according to the project of the diocesan architect M. Serotsinsky, a church building was erected in the name of the Saints Constantine and Helena in 1902 (Fig. 7) (it is located at the corner of Stefan cel Mare Boulevard and S. Lazo Street).

Alexander Asvadurov or Alexan Melsikhetikov Astavatsaduryants was engineer and architect [14]. After graduating from the St. Petersburg Institute of Civil Engineering department, he worked as city architect in Akkerman. In 19051910 according to his project the building of the sisters of mercy of Hârbovăț community was built (today it is at the corner of Vlaicu Pârcălab and V. Micle Streets). Also at the central cemetery located on Armeniasca Street a chapel which was built in 1916 according to his project.

Alexey Viktorovich Shchusev is a great architect of the XIX-XX centuries, a talented Master with a capital letter, whose architectural heritage continues to delight and surprise us today with both the perfection of forms and the versatility of brilliant ideas in the field of architecture. In 19121916 in Bessarabia, according to the project of A. Shchusev a church was built in the village Cuhuresti de Sus according to the ancient samples of Moldavian temples. The National Archives of the Republic of Moldova keeps the documents on the 


\section{Arta antică, medievală si modernă}

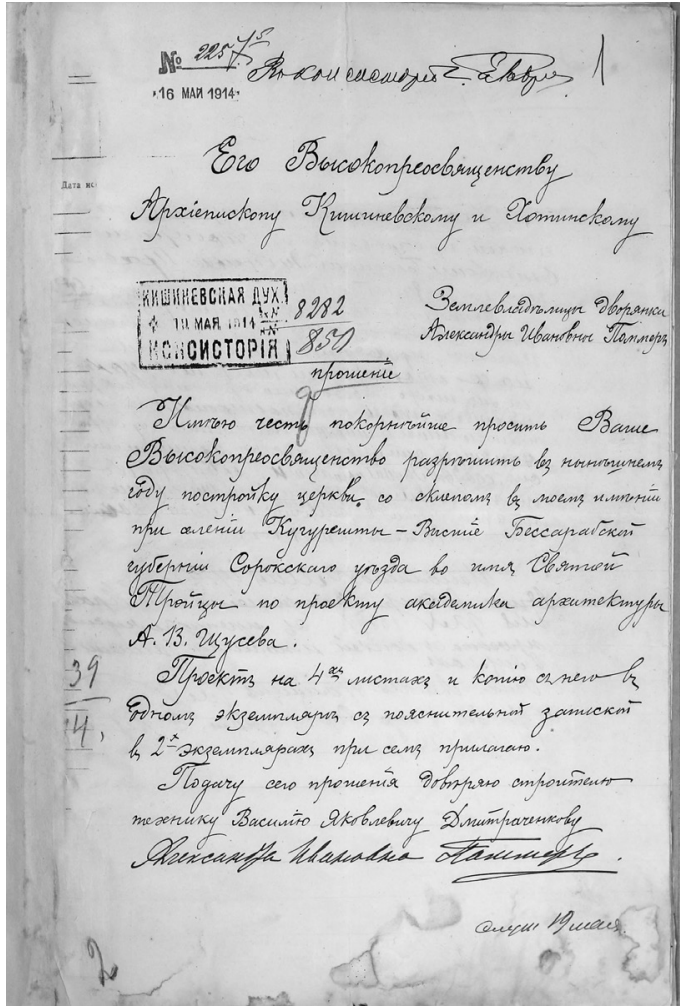

Fig. 8. The request of A. Pomer about the erection of the Holy Trinity church according to the project of

A. Schusev in the village Cuhuresti de Sus (NARM).

construction of this church [16]. In 1914 the noblewoman Alexandra Ivanovna Pommer turned to the Chisinau and Hotin Archbishop with a request to build a stone church in the name of the Holy Trinity with a family crypt, designed by the academician of architecture A. V. Shchusev in the village Cuhurestii de Sus of Soroca district [16, p. 1] (Fig. 8). The technician-builder Dmitrichenko helped in the construction of this church and followed all the instructions of Alexey Viktorovich. "He carefully created this church from local limestone, perfectly completing its exterior with rough stone of irregular shape, well drawn architectural details and thus, created a building in Moldova which is-unique of its kind" [29, p. 81, 86]. In 1917, from the report of the Dean Priest of Chernoutsan, it becomes known that in May the building of the church was completely finished both outside and inside.

At the end of 1916, in a Russian character, Aleksey Viktorovich prepared a project for an orphanage for the children of the fallen soldiers near Chisinau "On the initiative of Archbishop Platon (Rozhdestvensky) Exarch of Georgia, on a plot of diocesan land with an area of 120 acres, it was planned to create a shelter with a school, a home for the disabled, elderly priests, a hotel, a hospital and a church" [22. p. 212]. The total cost of the shelter was estimated as the sum of 700,000 rubles" [20, p. 490]. The project as a whole was adopted, but, unfortunately, it was not possible to implement it. The historian of Russian architecture V. A. Revzin, dedicated the essay "From the Temple to Mausoleum" [25] to great architect, in which he emphasized the highest professional level of all Shchusevs' projects, "and this irrefutably testifies to the fact that they were all made by the hand of the Maker. He was the Master, who built more than 20 churches during the fifteen pre-revolutionary years" [25, p. 190].

Thus, this article presents both published materials and archival documents, some projects of temples related to the architectural practice of religious buildings in Bessarabia, starting from the second half of XIX century and up to 1917, thanks to which new facets of the talents of Bessarabian architects and their authorial approaches become more obvious and of interest, both for architectural analysis, studying different styles and methods, and, in general, for the preservation of the rich cultural heritage of the Republic of Moldova.

\section{Bibliography:}

1. Ceastina A. "Arhitectul Luca Zaușkevich (1807după 1859)”). În: Identitățile Chișinăului. Ediția IV. Conferința științifică internațională. Chișinău, Editura Arc, 2018, p. 154-160.

2. Ceastina A. "The famous architect Alexander Iosif Bernardazzi (1831-1907) and his first projects in Bessarabia” Revista “Арта”, anul 2016, p. 38-43.

3. GAOO or State Archive of Odessa and Odessa region, F. 1, inv. 214, d. 12.

4. NARM or National Archive of Republic of Moldova, F. 2, inv. 2, d. 82.

5. NARM, F. 6, inv. 2, d. 649.

6. NARM F. 2, inv. 1, d. 3225.

7. NARM, F.2. inv.1, d. 6350.

8. NARM, F. 6, inv.4, d. 2323.

9. NARM, F. 6, inv. 11, d. 35.

10. NARM, F. 6, inv. 4, d. 102.

11. NARM, F. 6, inv. 4, d. 1231.

12. NARM, F. 75, inv.1, d. 1376,

13. NARM, F. 6, inv. 4. d. 312.

14. NARM, F. 6, inv. 11, d. 409, 418.

15. NARM, F. 6, inv. 4, d. 48.

16. NARM, F. 208, inv. 4, d. 4425.

17. RGIA or Russian State Historical Archive, F. 218, inv. 4, d. 1954.

18. RGIA, F. 796, inv. 179, d. 274.

19. А. И. Бернардацци (Биографический очерк). В: Зодчий. Журнал Архитектурный и научно-технический, выпуск 8, Санкт-Петербург, 1900 г., с. 98-101./ A.I. Bernardazzi (Biograficheskii ocherk). 


\section{Arta antică, medievală si modernă}

In: Zodchii. Jurnal arhitecturnyii i hudojestvenno-tehnicheskii, Sanct-Peterburg, 1900 vypusc VIII, s. 98-101.

20. Архитектурно-художественный журнал, год Ш, №51, Петроград, Академия Художеств, 1916, c.490. / Arhitecturno-hudojestvennyi jurnal, god III, №51, Petrograd, Academia Hudojestv, 1916, p. 490.

21. Бубис И. М. Зодчие Бернардацци. Кишинэу, Молдова, Louisville, Kentucky USA, 1997./ Bubis I. M. Zodchie Bernardazzi. Kishineu, Moldova, Louisville, Kentucky USA, 1997.

22. Кейпен-Вардиц Д. В. Храмовое зодчество A.В. Щусева. М.: Совпадение, 2013. / Keipen-Vardits D. V. Hramovoie zodchestvo A. V. Schuseva. M.: Sovpadenie, 2013.

23. Молдавско-русские взаимосвязи в искусстве в лицах и персоналиях (XVIII- I половина XX). Библиографический словарь-справочник в двух томах. Авторы-составители: Константин Шишкан, Сергей Пожар. Кишинев, Tipografia centrala, 2009. / Moldavsco-russkie vzaimosveazi v iskusstve v litsah I personaliah (XVIII - I polovina XX). Bibliograficheskii slovari-spravochnic v dvuh tomah. Avtory-sostaviteli: Konstantin Shishcan, Sergei Pojar. Kishinev, Tipografia centrala, 2009.

24. Перечень памятников, охраняемых государством. В Мониторул Парламента Республики Молдова, 1994, ст. 4., с. 17./Perecheni pamiatnicov, ohraneaemyh gosudarstvom. In: Monitorul Parlamenta Respublici Moldova, 1994, statia 4, s. 17.

25. Резвин В. А. Архитекторы и власть, Москва: Искусство XXI век, 2013, с. 177-190. / Rezvin V.A. Arhitectory I vlasti, Moscva: Iscusstvo XXI vec, 2013, p. 177-190.

26. Частина Алла, Историографический обзор документов, связанных с жизнью и деятельностью выдающегося архитектора А. И. Бернардацци (1831-1907) в Бессарабии (по материалам Национального Архива Республики Молдова). În: Culrgere de studii/ Univ. Pedagogică de Stat "Ion Creangă” din Chișinău. Patrpimoniului cultural: cercetare și valorificare. Ch., Garomont Studio, 2018, p. 224-231.
/ Chastina A. Istoriograficheskii obzor documentov, sveazannyh s jizniu I deatelinostiu vydaiuschegosea arhitectora A. I. Bernardazzi (1831-1907) v Bessarabii ( po materialam Natsionalinogo Arhiva Respublici Moldova). ). În: Culrgere de studii/ Univ. Pedagogică de Stat «Ion Creangă» din Chișinău. Patrpimoniului cultural: cercetare și valorificare. Ch., Garomont Studio, 2018, p. 224-231.

27. Частина А. Серафимовский дом - один из главных проектов епархиального архитектора Георгия Купчи. În: Materialele conferinței științifice naționale, dedicate celor 80 de ani de la trecerea la Domnului a protoiereiului Mihail Ceachir (18611938), mun. Chșinău, 10 septembrie, 2018. Chișinău: Lexon-Prim, 2020, p. 247-256. / Chastina A. Serafimovskii dom - odin iz glavnyh proiectov eparhialinogo arhitectora Gheorgia Kupchi. In: Materialele conferinței științifice naționale, dedicate celor 80 de ani de la trecerea la Domnului a protoiereiului Mihail Ceachir (1861-1938), mun. Chșinău, 10 septembrie, 2018. Chișinău: Lexon-Prim, 2020, p. 247-256.

28. Частина А. Архитектор Леопольд Шейдевандт и его проект Кишиневского женского епархиального училища. În: Culegere de studii/ Univ. Pedagogică de Stat „Ion Creangă” din Chișinău. Patrpimoniului cultural: cercetare și valorificare. Ch., Garomont Studio, 2020, p. 133-143. /Chastina A. Arhitector Leopolid Sheidevandt i ego proect Kishinevscogo eparhialinogo uchilischa. În: Culrgere de studii/ Univ. Pedagogică de Stat „Ion Creangă” din Chișinău. Patrpimoniului cultural: cercetare și valorificare. Ch., Garomont Studio, 2020, p. 133-143.

29. Щусев П. В. Страницы из жизни академика А. В. Щусева. М.: С.Э. Гордеев, 2011. / Schusev P.V. Stranitsy iz jizni academica A.V. Schuseva. M. S.E. Gordeev, 2011.

30. http://protopopiat-criuleni-dubasari.md 